\title{
Reaksi Pasar Atas Dividend Initiation dan Dividend Omission
}

\author{
Ni Putu Adi Pertiwi ${ }^{1}$ \\ Dewa Gede Wirama ${ }^{2}$ \\ ${ }^{1,2}$ Fakultas Ekonomi dan Bisnis Universitas Udayana (Unud), Bali, Indonesia \\ e-mail: niputuadipertiwi@yahoo.com
}

\begin{abstract}
ABSTRAK
Pengumuman dividend initiation dan dividend omission merupakan kebijakan yang dapat memengaruhi keputusan investor dalam berinvestasi. Perubahan dividen dapat merupakan sinyal mengenai kinerja perusahaan di masa yang akan datang. Tujuan penelitian ini adalah untuk menganalisis reaksi pasar atas dividend initiation dan dividend omission. Penelitian ini dilakukan di Bursa Efek Indonesia dengan periode penelitian selama 10 tahun yaitu dari tahun 2008 sampai dengan 2017. Sampel penelitian berjumlah 91 perusahaan untuk dividend initiation dan 80 perusahaan untuk dividend omission. Sampel ditentukan dengan metode purposive sampling. Hasil pengujian one sample t-test menunjukkan bahwa pasar bereaksi negatif atas dividend omission, namun tidak ada reaksi atas dividend initiation.

Kata Kunci: Dividend initiation, dividend omission, reaksi pasar
\end{abstract}

\begin{abstract}
Dividend initiation and dividend omission announcements are policies that can influence investor decisions in investing. Dividend changes can be a signal about the company's performance in the future. The purpose of this study is to analyze at market reactions to dividend initiation and dividend omission. This research was conducted on the Indonesia Stock Exchange with a research period of 10 years, from 2008 to 2017. The research sample were 91 companies for dividend initiation and 80 companies for dividend omission. Samples are determined by purposive sampling method. The results of the one sample t-test show that the market reacts negatively to dividend omission, but there is no reaction to dividend initiation.
\end{abstract}

Keywords: Dividend initiation, dividend omission, market reaction

\section{PENDAHULUAN}

Dalam keputusan pembagian dividen, perusahaan perlu mempertimbangkan kelangsungan hidup dan pertumbuhan perusahaan. Dengan demikian laba tidak seluruhnya dibagikan ke dalam bentuk dividen namun perlu disisihkan untuk diinvestasikan kembali (Purwanto, 2013).

Dividen sering digunakan oleh para investor untuk menilai risiko dan laba perusahaan, sebab dividen mempunyai kandungan informasi. Pembayaran dividen yang meningkat ditafsirkan sebagai tanda meningkatnya keuntungan perusahaan 
Ni Putu Adi Pertiwi dan Dewa Gede Wirama. Reaksi...

di masa yang akan datang dan menurunnya tingkat pembayaran dividen ditafsirkan sebagai tanda menurunnya keuntungan perusahaan di masa mendatang. Jadi, setiap perubahan kebijakan dividen sekecil apapun dianggap mampu memengaruhi reaksi investor dan akhirnya dapat memengaruhi harga saham (Wicaksono, 2016)

Dalam suatu pembagian dividen ada tiga tanggal yang perlu diperhatikan, yaitu (Purwanto, 2013): Tanggal pengumuman dividen merupakan tanggal resmi pengumuman oleh emiten tentang bentuk dan besarnya serta jadwal pembayaran dividen yang akan dilakukan. Tanggal dimana seorang harus tercatat sebagai pemegang saham perusahaan publik atau emiten, sehingga ia mempunyai hak memperoleh dividen yang diperuntukkan bagi pemegang saham. Tanggal pembayaran adalah tanggal dimana dividen dibayarkan kepada investor.

Beberapa perusahaan go public di Bursa Efek Indonesia seperti Astra International Tbk, Bank Central Asia Tbk, dan HM Sampoerna Tbk rutin membagikan dividen dari tahun 2008 sampai tahun 2017. Pembagian dividen yang rutin tersebut membuat perusahaan terlihat mapan di mata investor, karena perusahaan mampu membagikan labanya kepada para pemegang saham. Risiko akan fluktuasi harga saham membuat sebagian investor lebih memilih perusahaan yang rutin membagikan dividen daripada perusahaan yang tidak membagikan dividen. Perusahaan lainnya seperti Aneka Tambang Tbk tiba-tiba tidak membagikan dividen setelah sebelumnya rutin membagikan dividen. Aneka Tambang Tbk rutin membagikan dividen dari tahun 2008 sampai 2014, dan tidak membagikan dividen pada tahun 2015 sampai 2017. Ada juga perusahaan yang 
sebelumnya rutin tidak membagikan dividen, lalu membagikan dividen pertama kalinya seperti Indofarma Tbk. Indofarma Tbk membagikan dividen pertama kalinya tahun 2013 setelah sebelumnya tidak membagikan dividen dari tahun 2008 sampai tahun 2012. Adanya perubahan kebijakan perusahaan terhadap dividen dapat memengaruhi perilaku investor di pasar modal. Ekspektasi investor terhadap prospek perusahaan akan berubah jika ada perubahan kebijakan dividen.

Perusahaan melakukan perubahan kebijakan dividen dengan berbagai alasan, misalnya kebijakan pembayaran dividen pertama kali setelah beberapa tahun tidak membayar dividen (dividend initiation) dilakukan untuk memberi informasi bagi investor akan prospek laba perusahaan yang lebih baik untuk saat ini dan di masa depan. Dividen inisiasi adalah pembayaran dividen tunai pertama kalinya setelah minimal dua kali berturut-turut tidak membayar dividen tunai selama beberapa periode. Perusahaan yang menetapkan kebijakan membayar dividen pertama kali (dividend initiation) merupakan sinyal dan pasar akan bereaksi positif. Perusahaan tidak akan membagikan dividen apabila prospek pertumbuhan laba dan arus kas masa depan kurang baik. Pengumuman terhadap penghapusan dividen untuk pertama kalinya setelah dua kali berturut-turut membagikan dividen (dividend omission) tidak semuanya direspon dengan negatif, pada umumnya ketika perusahaan tidak membayar dividen dianggap prospek perusahaan di masa yang akan datang kurang bagus. Perusahaan yang menghapus atau tidak membayar dividen belum tentu merupakan perusahaan yang tidak berkualitas. Sebab ada kemungkinan perusahaan yang menunda 
Ni Putu Adi Pertiwi dan Dewa Gede Wirama. Reaksi...

pembayaran dividennya, laba yang diperoleh digunakan untuk membiayai investasinya (Purwanto, 2013).

Setiap melakukan investasi pada pasar modal, pelaku pasar perlu mendapatkan informasi untuk mendukung analisis dan prediksi mengenai ketepatan dalam menginvestasikan dana untuk mendapat keuntungan yang diharapkan. Informasi yang tersedia di pasar modal memiliki peranan yang penting untuk memengaruhi segala macam bentuk transaksi perdagangan yang ada di pasar modal karena para pelaku pasar modal akan melakukan analisis lebih lanjut terhadap setiap pengumuman atau informasi yang masuk ke bursa efek tersebut (Wicaksono, 2016)

Pelaku pasar modal akan selalu memperhatikan setiap pengumuman yang disampaikan oleh perusahaan. Jika pengumuman mengandung informasi (information content), maka diharapkan pasar akan bereaksi pada waktu pengumuman tersebut diterima. Reaksi pasar ditunjukkan dengan adanya perubahan harga dari sekuritas bersangkutan. Reaksi ini dapat diukur dengan menggunakan return sebagai nilai perubahan harga atau dengan menggunakan abnormal return. Jika digunakan abnormal return, maka dapat dikatakan bahwa suatu pengumuman yang mempunyai kandungan informasi akan memberikan abnormal return kepada pasar. Sebaliknya yang tidak mengandung informasi tidak memberikan abnormal return kepada pasar (Hartono, 2017:644).

Penelitian yang dilakukan oleh (Asquith dan Mullins, 1983) meneliti 160 perusahaan yang melakukan dividend initiation dengan periode penelitian 10 tahun, mendapatkan hasil bahwa dividend initiation meningkatkan kekayaan 
investor. Hal tersebut berarti pasar bereaksi positif atas pengumuman dividend initiation. Penelitian sebelumnya yang dilakukan oleh (Dharmarathne, 2013) menyatakan bahwa pasar bereaksi positif atas pengumuman dividen di pasar modal Sri Lanka. Pengumuman inisiasi dividen berpengaruh positif signifikan terhadap nilai abnormal return dinyatakan oleh (Purwanto, 2013). Penelitian lainnya yang dilakukan oleh Sare et al (2014) menyatakan bahwa pengumuman dividend initiation disambut positif oleh investor di Bursa Efek Ghana. Serupa dengan penelitian sebelumnya, (Indrawati, 2013) menyatakan bahwa variabel dividend initiation sebelum pengumuman tidak berpengaruh positif dan signifikan terhadap reaksi pasar. Penelitian yang dilakukan oleh (Wicaksono, 2016), menyatakan bahwa tidak terdapat perbedaan abnormal return sebelum dan sesudah pengumuman dividend initiation. Pasar dinyatakan tidak bereaksi atas pengumuman dividend initiation oleh (Sharma dan Pandey, 2015) yang melakukan penelitian di Bursa Efek India dengan periode penelitian 10 tahun.

Dividen omisi berpengaruh negatif signifikan terhadap abnormal return dinyatakan oleh (Purwanto, 2013). Reaksi pasar yang negatif terhadap dividend omission juga dijelaskan dalam penelitian (Handayani, 2015). Serupa dengan penelitian sebelumnya, (Chelimo dan Kiprop, 2017) yang melakukan penelitian di Bursa Efek Nairobi dengan periode penelitian 10 tahun menyatakan bahwa penurunan jumlah pembayaran dividen menyebabkan penurunan harga saham di Bursa Efek Nairobi. Berbeda dengan penelitian sebelumnya, penelitian yang dilakukan oleh (Sharma dan Pandey, 2015) menemukan reaksi pasar yang positif atas pengumuman dividend omission di Bursa Efek India dengan periode 
Ni Putu Adi Pertiwi dan Dewa Gede Wirama. Reaksi...

penelitian 10 tahun. Penelitian lainnya yang dilakukan oleh (Wicaksono 2016) menemukan tidak ada perbedaan antara rata-rata abnormal return saham yang signifikan sebelum dan sesudah pengumuman dividend omission.

Signalling theory mengemukakan tentang bagaimana seharusnya sebuah perusahaan memberikan sinyal kepada pengguna laporan keuangan. Sinyal ini berupa informasi mengenai apa yang sudah dilakukan oleh manajemen untuk merealisasikan keinginan pemilik. Sinyal dapat berupa promosi atau informasi lain yang menyatakan bahwa perusahaan tersebut lebih baik daripada perusahaan lain. Teori sinyal menjelaskan bahwa pemberian sinyal dilakukan oleh manajer untuk mengurangi asimetri informasi. Manajer memberikan informasi melalui laporan keuangan bahwa mereka menerapkan kebijakan akuntansi konservatisme yang menghasilkan laba yang lebih berkualitas karena prinsip ini mencegah perusahaan melakukan tindakan membesar-besarkan laba dan membantu pengguna laporan keuangan dengan menyajikan laba dan aktiva yang tidak overstate (Purwanto, 2013).

Signalling theory memberikan sinyal terhadap pasar dengan tujuan menarik perhatian investor. Saat pengumuman dipublikasikan maka pelaku pasar menganalisis dan memilih informasi yang baik (good news) atau informasi yang buruk (bad news). Jika informasi tersebut dianggap sebagai sinyal baik, maka terjadi perubahan pada volume perdagangan saham (Suparsa, 2014).

Kenaikan dividen merupakan hipotesis sementara suatu penghasilan yang baik di masa mendatang oleh manajemen perusahaan yang akan memberi sinyal kepada para investor. Sebaliknya, suatu penurunan dividen diyakini investor 
sebagai suatu sinyal bahwa perusahaan menghadapi masa sulit di waktu mendatang. Hal ini mengakibatkan terjadinya risiko investasi dikarenakan adanya penyimpangan antara harapan investor yang menginginkan dividen tinggi (Fadhilah, 2017).

Myron Gordon dan John Lintner mengembangkan mengembangkan bird in the hand theory. Mereka berpendapat bahwa ada hubungan antara tingkat pembayaran dividen dengan nilai perusahaan. Karena investor menilai capital gain lebih berisiko daripada dividen, perusahaan harus memiliki rasio pembayaran dividen yang lebih tinggi untuk memaksimalkan harga saham. Dengan kata lain, pembayaran dividen yang tinggi akan menaikkan harga saham (Priya, 2016).

Gordon dan Lintner menyatakan bahwa aliran dividen di masa mendatang akan didiskonto pada tingkat yang lebih rendah daripada keuntungan modal harapan. Anggapan tersebut diformulasikan dalam model penelitian saham Gordon (Gordon Valuation Model) yang menyatakan bahwa saham perusahaan akan dihargai lebih tinggi jika dividen harapannya lebih tinggi dibandingkan dengan perushaaan yang dividennya lebih rendah (Gumanti, 2013:8).

Teori ini menjelaskan bahwa investor menghendaki pembayaran dividen yang tinggi dari keuntungan perusahaan sesuai tujuan investor yaitu menanamkan sahamnya untuk mendapatkan dividen, investor tidak ingin berinvestasi di perusahaan jika penerimaan dividen dalam jangka waktu yang lama. Investor akan bersedia membayar harga yang lebih tinggi untuk perusahaan yang membayarkan dividen saat ini. Pembayaran dividen saat ini terjadi karena ada anggapan bahwa mendapat dividen saat ini risikonya lebih kecil dari pada mendapat capital gain di 
Ni Putu Adi Pertiwi dan Dewa Gede Wirama. Reaksi...

masa yang akan datang meskipun capital gain di masa mendatang dapat memberikan pengembalian yang lebih tinggi dari pada dividen saat ini, selain risiko juga adanya ketidakpastian tentang arus kas perusahaan dimasa depan. Teori ini juga berpendapat bahwa kas ditangan dalam bentuk dividen lebih bernilai dari pada kekayaan dalam bentuk lain dengan istilah "para investor memandang satu burung ditangan lebih berharga dari pada seribu burung di udara" (Muhajir, 2016).

Pasar dikatakan efisien dalam bentuk lemah jika harga-harga dari sekuritas mencerminkan secara penuh (fully reflect) informasi masa lalu. Informasi masa lalu ini merupakan informasi yang sudah terjadi. Bentuk efisiensi pasar secara lemah ini berkaitan dengan teori langkah awal (random walk theory) yang menyatakan bahwa data pasar efisien secara bentuk lemah, maka nilai-nilai masa lalu tidak dapat digunakan untuk memprediksi harga sekarang. Ini berarti bahwa untuk pasar yang efisien bentuk lemah, investor tidak dapat menggunakan informasi masa lalu untuk mendapatkan keuntungan yang tidak normal.

Pasar dikatakan efisien setengah kuat jika harga-harga sekuritas secara penuh mencerminkan (fully reflect) semua informasi yang dipublikasikan (all publicy available information) termasuk informasi yang berada di laporan-laporan keuangan perusahaan emiten. Informasi yang dipublikasikan dapat berupa sebagai berikut ini: Informasi yang dipublikasikan yang hanya memengaruhi harga sekuritas dari perusahaan yang mempublikasikan informasi tersebut. Informasi yang dipublikasikan ini merupakan informasi dalam bentuk pengumuman oleh perusahaan emiten. Informasi ini umumnya berhubungan dengan peristiwa yang 
terjadi di perusahaan emiten (corporate event). Contoh dari informasi yang dipublikasikan misalnya adalah pengumuman laba, pengumuman pembagian dividen, pengumuman pengembangan produk baru, pengumuman merjer dan akuisisi, pengumuman perubahan metode akuntansi, pengumuman pergantian pemimpin perusahaan dan lain sebagainya.

Informasi yang dipublikasikan memengaruhi harga-harga sekuritas sejumlah perusahaan. Informasi yang dipublikasikan ini dapat berupa peraturan pemerintah atau peraturan dari regulator yang hanya berdampak pada harga-harga sekuritas perusahaan-perusahaan yang terkena regulasi tersebut. Contoh dari informasi ini misalnya adalah regulasi untuk meningkatkan kebutuhan cadangan (reserved requirement) yang harus dipenuhi oleh semua bank-bank. Informasi ini akan memengaruhi secara langsung harga sekuritas tidak hanya sebuah bank saja tetapi mungkin semua emiten di dalam industri perbankan.

Informasi yang dipublikasikan memengaruhi harga-harga sekuritas semua perusahaan yang terdaftar di pasar saham. Informasi ini dapat berupa peraturan pemerintah atau peraturan dari regulator yang berdampak ke semua perusahaan emiten. Contoh dari regulasi ini adalah peraturan akuntansi untuk mencantumkan laporan arus kas yang harus dilakukan oleh semua perusahaan. Regulasi ini akan mempunyai dampak ke harga sekuritas tidak hanya untuk sebuah perusahaan saja atau perusahaan-perusahaan di suatu industri, tetapi mungkin berdampak langsung pada semua perusahaan.

Pasar dikatakan efisien dalam bentuk kuat jika harga-harga sekuritas secara penuh mencerminkan (fully reflect) semua informasi yang tersedia termasuk 
Ni Putu Adi Pertiwi dan Dewa Gede Wirama. Reaksi...

informasi privat. Jika pasar efisien dalam bentuk ini, maka tidak ada individual investor atau grup dari investor yang dapat memperoleh keuntungan tidak normal (abnormal return) karena mempunyai informasi privat.

Abnormal return atau excess return merupakan kelebihan dari return yang sesungguhnya terjadi terhadap return normal (Hartono, 2016:667). Return normal merupakan return ekspektasian (return yang diharapkan oleh investor). Dengan demikian return tak normal (abnormal return) adalah selisih antara return sesungguhnya yang terjadi dengan return ekspektasian. (Brown dan Warner, 1985) mengestimasi return ekspektasian menggunakan model estimasi meanadjusted model, market model, dan market-adjusted model.

Model sesuaian rata-rata (mean-adjusted model) ini menganggap bahwa return ekspektasian bernilai konstan yang sama dengan rata-rata return realisasian sebelumnya selama periode estimasi (estimation period), sebagai berikut:

$$
\mathrm{E}\left[\mathrm{R}_{\mathrm{i}, \mathrm{t}}\right]=\frac{\sum_{j=t 1}^{t 2} R_{i, j}}{T}
$$

Keterangan :

$\mathrm{E}\left[\mathrm{R}_{\mathrm{i}, \mathrm{t}}\right]=$ return ekspektasian sekuritas ke-i pada periode peristiwa ke-t

$\mathrm{R}_{\mathrm{i}, \mathrm{j}} \quad=$ return realisasian sekuritas ke-i pada periode estimasi ke-j

$\mathrm{T}=$ lamanya periode estimasi, yaitu dari $\mathrm{t} 1$ sampai dengan $\mathrm{t} 2$

Periode estimasi (estimation period) umumnya merupakan periode sebelum periode peristiwa. Periode peristiwa (event period) disebut juga dengan periode pengamatan atau jendela peristiwa (event window). Periode estimasi dan periode jendela dapat dilihat pada gambar di bawah ini.

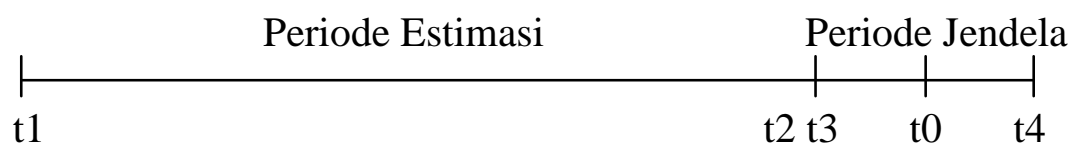


Perhitungan return eskpektasian dengan model pasar (market model) ini dilakukan dengan dua tahap, yaitu (1) membentuk model ekspektasi dengan menggunakan data realisasi selama periode estimasi dan (2) menggunakan model ekspektasi ini untuk mengestimasi return ekspektasian di periode jendela. Model ekspektasi dapat dibentuk menggunakan teknik regresi OLS (Ordinary Least Square) dengan persamaan:

$$
\mathrm{R}_{\mathrm{i}, \mathrm{j}}=\alpha_{\mathrm{i}}+\beta_{\mathrm{i}} . \mathrm{R}_{\mathrm{Mj}}+\varepsilon_{\mathrm{i}, \mathrm{j}}
$$

Keterangan:

$\mathrm{R}_{\mathrm{i}, \mathrm{j}} \quad=$ return realisasian sekuritas ke-i pada periode estimasi ke- $\mathrm{j}$

$\alpha_{\mathrm{i}} \quad=$ intercept untuk sekuritas ke-i

$\beta_{\mathrm{i}} \quad=$ koefisien slope yang merupakan Beta dari sekuritas ke-i

$\mathrm{R}_{\mathrm{Mj}} \quad=$ return indeks pasar pada periode estimasi ke-j yang dapat dihitung dengan rumus $\mathrm{R}_{\mathrm{MJ}}=\left(\mathrm{IHSG}_{\mathrm{j}}-\mathrm{IHSG}_{\mathrm{j}-1}\right) / \mathrm{IHSG}_{\mathrm{j}-1}$ dengan IHSG adalah Indeks Harga Saham Gabungan

$\varepsilon_{\mathrm{i}, \mathrm{j}} \quad=$ kesalahan residu sekuritas ke-I pada periode estimasi ke-j

Model sesuaian pasar (market-adjusted model) menganggap bahwa praduga yang terbaik untuk mengestimasi return suatu sekuritas adalah return indeks pasar pada saat tersebut. Dengan menggunakan model ini, maka tidak perlu menggunakan periode estimasi untuk membentuk model estimasi, karena return sekuritas yang diestimasi adalah sama dengan return indeks pasar.

Studi peristiwa (event study) merupakan studi yang mempelajari reaksi pasar terhadap suatu peristiwa (event) yang informasinya dipublikasikan sebagai suatu pengumuman. Event study dapat digunakan untuk menguji kandungan informasi (information content) dari suatu pengumuman dan dapat juga digunakan untuk menguji efisiensi pasar bentuk setengah kuat (Hartono, 2016:643). 
Ni Putu Adi Pertiwi dan Dewa Gede Wirama. Reaksi...

Pengujian kandungan informasi dan pengujian efisiensi pasar bentuk setengah kuat merupakan dua pengujian yang berbeda. Pengujian kandungan informasi dimaksudkan untuk melihat reaksi dari suatu pengumuman. Jika pengumuman mengandung informasi (information content), maka diharapkan pasar akan bereaksi pada waktu pengumuman tersebut diterima oleh pasar. Reaksi pasar ditunjukkan dengan adanya perubahan harga dari sekuritas bersangkutan. Reaksi ini dapat diukur dengan menggunakan return sebagai nilai perubahan harga atau dengan menggunakan abnormal return. Jika digunakan abnormal return, maka dapat dikatakan bahwa suatu pengumuman yang mempunyai kandungan informasi akan memberikan abnormal return kepada pasar. Sebaliknya yang tidak mengandung informasi tidak memberikan abnormal return kepada pasar (Hartono, 2016:644).

Penelitian sebelumnya menjelaskan hasil yang berbeda-beda terkait dengan diviend initiation dan dividend omission, hal tersebut dapat dipengaruhi oleh periode penelitian ataupun tempat penelitian, sehingga menyebabkan sampel yang diperoleh berbeda-beda. Peneliti memutuskan untuk menggunakan periode penelitian selama 10 tahun yaitu dari tahun 2008 sampai tahun 2017, karena memerlukan waktu minimal 2 tahun berturut-turut tidak membagikan dividen untuk dividend initiation dan minimal 2 tahun berturut-turut membagikan dividen untuk meneliti dividend omission. Oleh karena itu, diperlukan periode waktu penelitian yang cukup panjang untuk memperoleh sampel. Selain itu, peneliti juga mengacu pada penelitian sebelumnya yang menggunakan periode penelitian selama 10 tahun. 
Pengumuman dividen dianggap sebagai alat untuk menginformasikan kepada investor bahwa perusahaan berkinerja baik dan mempunyai harapan kelangsungan usaha yang lebih panjang (going cocern). Perusahaan yang membagikan dividen untuk pertama kalinya setelah dua kali berturut-turut tidak membagikan dividen dapat memberikan informasi yang positif kepada pasar (good news). Dengan adanya informasi pembagian dividen oleh perusahaan, investor akan bereaksi terhadap informasi tersebut dengan ditunjukkan oleh peningkatan jumlah transaksi saham perusahaan. Hal ini sejalan dengan konsep bird in the hand theory yang beranggapan bahwa investor lebih menyukai dividen daripada capital gain .

Penelitian sebelumnya yang menyatakan adanya reaksi pasar positif terhadap pengumuman dividend initiation antara lain, (Asquith dan Mullins, 1983), (Dharmarathne 2013), (Sare et al, 2014), dan (Purwanto, 2013). Mengacu pada penelitian sebelumnya yang menguji tentang reaksi pasar terhadap pengumuman dividend initiation, maka dapat dirumuskan hipotesis sebagai berikut:

$\mathrm{H}_{1}$ : Pasar bereaksi positif atas pengumuman dividend initiation

Pengumuman penghapusan dividen pertama kalinya setelah dua kali berturut-turut perusahaan melakukan pembagian dividen dianggap sebagai informasi negatif (bad news). Sesuai dengan bird in the hand theory yang menyatakan bahwa investor lebih menyukai untuk menerima dividen daripada capital gain, maka adanya penghapusan dividen yang dilakukan oleh perusahaan, menyebabkan investor tidak tertarik lagi untuk berinvestasi di perusahaan 
Ni Putu Adi Pertiwi dan Dewa Gede Wirama. Reaksi...

tersebut. Hal tersebut menyebabkan investor berinvestasi di perusahaan lain yang selalu membagikan dividen.

Penelitian sebelumnya yang menyatakan adanya reaksi pasar negatif terhadap pengumuman dividend omission antara lain penelitian dari Purwanto (2013), Handayani (2015), dan Chelimo dan Kiprop (2017). Mengacu pada penelitian sebelumnya yang menguji tentang reaksi pasar atas dividend omission, maka dapat dirumuskan hipotesis sebagai berikut:

$\mathrm{H}_{2}$ : Pasar bereaksi negatif atas pengumuman dividend omission

\section{METODE PENELITIAN}

Penelitian ini dilakukan pada perusahaan-perusahaan yang terdaftar di Bursa Efek Indonesia periode 2008-2017. Data perusahaan-perusahaan yang digunakan dalam penelitian ini diperoleh dari www.idx.co.id, www.ksei.co.id, dan www.finance.yahoo.com. Lokasi penelitian dilakukan di Bursa Efek Indonesia karena tersedianya data yang lengkap terkait dengan penelitian yang dilakukan. Objek penelitian yang diteliti adalah reaki pasar atas dividend initiation dan dividend omission pada perusahaan yang terdaftar di Bursa Efek Indonesia pada tahun 2008-2017. Variabel bebas dalam penelitian ini adalah variabel dividend initiation $\left(\mathrm{X}_{1}\right)$ dan dividend omission $\left(\mathrm{X}_{2}\right)$. Variabel terikat dalam penelitian ini adalah reaksi pasar (Y).

Actual return merupakan return yang terjadi sesungguhnya dan menunjukkan besarnya keuntungan investor yang menanamkan modalnya dalam 
bentuk saham biasa. Actual return dinyatakan dalam persentase dan dapat dihitung dengan rumus sebagai berikut:

$$
\mathrm{R}_{\mathrm{i}, \mathrm{t}}=\frac{P_{i, t}-P_{i, t-1}}{P_{i, t-1}}
$$

Keterangan:

$\mathrm{R}_{\mathrm{i}, \mathrm{t}} \quad=$ return sesungguhnya yang terjadi untuk sekuritas ke-i pada periode ke-t

$\mathrm{P}_{\mathrm{i}, \mathrm{t}} \quad$ = harga sekarang relatif

$\mathrm{P}_{\mathrm{i}, \mathrm{t}-1}=$ harga sebelumnya

Return ekspektasian (expected return) merupakan return yang digunakan untuk pengambilan keputusan investasi. Return ini penting dibandingkan dengan return historis karena return ekspektasian merupakan return yang diharapkan dari investor yang akan dilakukan. Expected return dinyatakan dalam persentase. Berikut adalah rumus menghitung expected return dengan market adjusted-model:

$$
\mathrm{ER}_{\mathrm{i}, \mathrm{t}}=\frac{I H S G_{t}-I H S G_{t-1}}{I H S G_{t-1}}
$$

Keterangan:

$\mathrm{ER}_{\mathrm{i}, \mathrm{t}}=$ expected return

$\mathrm{IHSG}_{\mathrm{t}}=$ Indeks Harga Saham Gabungan pada hari ke t

$\mathrm{IHSG}_{\mathrm{t}-1}=$ Indeks Harga Saham Gabungan pada hari ke t-1

Abnormal return merupakan selisih antara return sesungguhnya (actual return) dengan return ekspektasi (expected return). Abnormal return dinyatakan dalam persentase dan dapat dihitung dengan rumus sebagai berikut:

$$
\mathrm{AR}_{\mathrm{i}, \mathrm{t}}=\mathrm{R}_{\mathrm{i}, \mathrm{t}}-\mathrm{E}\left[\mathrm{R}_{\mathrm{i}, \mathrm{t}}\right]
$$

Keterangan:

$\mathrm{AR}_{\mathrm{i}, \mathrm{t}}=$ abnormal return sekuritas ke-i pada periode peristiwa ke-t

$\mathrm{R}_{\mathrm{i}, \mathrm{t}} \quad=$ return realisasi yang terjadi untuk sekuritas ke-i pada periode peristiwa ke- $\mathrm{t}$

$\mathrm{E}\left[\mathrm{R}_{\mathrm{i}, \mathrm{t}}\right]=$ expected return sekuritas ke-i untuk peristiwa ke-t 
Ni Putu Adi Pertiwi dan Dewa Gede Wirama. Reaksi...

Cumulative abnormal return adalah penjumlahan abnormal return suatu perusahaan selama periode amatan. Abnormal return terjadi ketika investor bereaksi terhadap suatu informasi atau peristiwa, akibat kenaikan atau penurunan harga saham. CAR dihitung dengan rumus sebagai berikut:

$\mathrm{CAR}=\sum \mathrm{AR}_{\mathrm{i},}$

Populasi dalam penelitian ini adalah saham-saham perusahaan yang terdaftar di BEI yang melakukan pembagian dividen tahun 2008-2017. Sampel dalam penelitian ini dipilih menggunakan metode purposive sampling, yang artinya pemilihan sampel didasarkan atas kriteria-kriteria tertentu. Berikut ini merupakan proses dan hasil seleksi sampel:

Tabel 1.

Proses dan Hasil Seleksi Sampel Dividend Initiation

\begin{tabular}{clc}
\hline No & \multicolumn{1}{c}{ Kriteria } & Jumlah Perusahaan \\
\hline 1 & $\begin{array}{l}\text { Perusahaan melakukan pembagian dividen pertama kalinya setelah } \\
\text { minimal 2 kali berturut-turut tidak melakukan pembagian dividen } \\
\text { dalam periode pengamatan. }\end{array}$ & 115 \\
2 & $\begin{array}{l}\text { Perusahaan melakukan corporate action lain (right issue, stock } \\
\text { split, merger, dan akuisisi) selama periode jendela (event window). }\end{array}$ \\
3 & $\begin{array}{l}\text { Perusahaan tidak memiliki data-data yang lengkap untuk } \\
\text { mendukung penelitian ini. } \\
\text { Jumlah perusahaan yang memenuhi kriteria sampel }\end{array}$ & (14) \\
\hline Sumber: Data diolah, 2018
\end{tabular}

Pengujian reaksi pasar dalam penelitian ini dilakukan dengan teknik event study yang merupakan studi yang mempelajari reaksi pasar terhadap suatu peristiwa (event) yang informasinya dipublikasikan sebagai suatu pengumuman (Hartono, 2016:623). Tanggal yang dianggap sebagai event date dalam penelitian ini adalah tanggal RUPS yang dilakukan oleh perusahaan terkait. Berdasarkan tanggal tersebut, periode peristiwa (event period) ada 3 hari, yaitu 1 hari sebelum event date, 1 hari saat event date, dan 1 hari setelah event date. Periode peristiwa 
3 hari dipilih agar tidak ada event lain yang memengaruhi reaksi pasar dalam mengambil keputusan. Penelitian ini menggunakan model sesuaian rata-rata dalam mengestimasi return ekspektasian, sehingga tidak perlu dibentuk model estimasi, karena return sekuritas yang diestimasi sama dengan return indeks pasar.

Tabel 2.

Proses dan Hasil Seleksi Sampel Dividend Omission

\begin{tabular}{clc}
\hline No & \multicolumn{1}{c}{ Kriteria } & $\begin{array}{c}\text { Jumlah } \\
\text { Perusaha } \\
\text { an }\end{array}$ \\
\hline 1 & $\begin{array}{l}\text { Perusahaan melakukan penghapusan dividen pertama kalinya setelah minimal } \\
\text { 2 kali berturut-turut melakukan pembagian dividen dalam periode pengamatan }\end{array}$ & 109 \\
2 & $\begin{array}{l}\text { Perusahaan melakukan corporate action lain (right issue, stock split, merger, } \\
\text { dan akuisisi) selama periode jendela (event window) }\end{array}$ & (14) \\
3 & $\begin{array}{l}\text { Perusahaan tidak memiliki data-data yang lengkap untuk mendukung } \\
\text { penelitian ini } \\
\text { Jumlah Perusahaan yang Memenuhi Kriteria Sampel }\end{array}$ & (4) \\
\hline
\end{tabular}
Sumber: Data diolah, 2018

Dalam penelitian ini digunakan uji one sample t-test untuk menganalisis tingkat signifikansi abnormal return di seputar tanggal pengumuman dividend initiation dan dividend omission. Uji one sample t-test merupakan uji yang digunakan untuk membandingkan satu variabel bebas. Tujuannya adalah untuk mengetahui signifikansi suatu nilai tertentu dengan rata-rata sampel. Jika nilai probabilitas lebih dari 5\%, maka tidak terdapat abnormal return di sekitar tanggal pengumuman dividend initiation dan dividend omission. Jika nilai probabilitas kurang dari $5 \%$, maka terdapat abnormal return di sekitar tanggal pengumuman dividend initiation dan dividend omission.

\section{HASIL DAN PEMBAHASAN}


Ni Putu Adi Pertiwi dan Dewa Gede Wirama. Reaksi...

Dari tabel 3 dapat dilihat bahwa secara statistik cumulative abnormal return (CAR) secara keseluruhan dengan 83 perusahaan yang digunakan selama 3 hari pengamatan, diperoleh nilai minimum sebesar -0,0806 yang dimiliki oleh Gema Grahasarana Tbk (sektor perdagangan, jasa, dan investasi). Nilai maksimum CAR sebesar 0,0678 dimiliki oleh Jembo Cable Company Tbk (sektor aneka industri). Nilai rata-rata CAR sebesar 0,0023, dengan standar deviasi sebesar 0,0322.

Tabel 3.

Hasil uji statistik deskriptif

\begin{tabular}{lrrrrr}
\hline & N & Minimum & Maximum & Mean & Std. Deviation \\
\hline CAR & 83 & -.0806 & .0678 & .0023 & .0322 \\
Valid N (listwise) & 83 & & & & \\
\hline
\end{tabular}
Sumber: Data diolah, 2018

Dari tabel 4 dapat dilihat bahwa secara statistik cumulative abnormal return (CAR) secara keseluruhan dengan 71 perusahaan yang digunakan selama 3 hari pengamatan, diperoleh nilai minimum sebesar -0,0579 yang dimiliki oleh Multistrada Arah Sarana Tbk (sektor aneka industri). Nilai maksimum CAR sebesar 0,0448 dimiliki oleh Aneka Tambang Tbk (sektor pertambangan). Nilai rata-rata CAR sebesar -0,0059, dengan standar deviasi sebesar 0,0233.

Tabel 4.

Hasil uji statistik deskriptif

\begin{tabular}{lrrrrr}
\hline & N & \multicolumn{1}{c}{ Minimum } & Maximum & \multicolumn{1}{c}{ Mean } & Std. Deviation \\
\hline CAR & 71 & -.0579 & .0448 & -.0059 & .0233 \\
Valid N (listwise) & 71 & & & & \\
\hline Sumber Datal & & & & & \\
\hline
\end{tabular}
Sumber: Data diolah, 2018

Dari tabel 5 dapat diketahui nilai dari signifikansi (asymptotic sig) dari cumulative abnormal return (CAR) atas pengumuman dividend initiation sebesar $0,200>0,05$, yang berarti bahwa data berdistribusi normal, sehingga dapat diteruskan analisisnya ke dalam statistik parametrik yaitu uji one sample t-test. 
Sebelumnya data perusahaan yang melakukan dividend initiation dihilangkan sejumlah 8 data karena terdeteksi sebagai data outlier.

Tabel 5.

Hasil Uji Normalitas

\begin{tabular}{llr}
\hline & & CAR \\
\hline Normal Parameters & & 83 \\
& Mean & .0023 \\
Most Extreme Differences & Std. Deviation & .0322 \\
& Absolute & .062 \\
& Positive & .039 \\
Test Statistic & Negative & -.062 \\
Asymp. Sig. (2-tailed) & & .062 \\
& & .200 \\
\hline
\end{tabular}

Sumber: Data diolah, 2018

Dari tabel 6 dapat diketahui nilai dari signifikansi (asymptotic sig) dari cumulative abnormal return (CAR) atas pengumuman dividend omission sebesar $0,200>0,05$, yang berarti bahwa data berdistribusi normal, sehingga dapat diteruskan analisisnya ke dalam statistik parametrik yaitu uji one sample t-test. Sebelumnya data perusahaan yang melakukan dividend omission dihilangkan sejumlah 9 data karena terdeteksi sebagai data outlier.

Tabel 6.

Hasil Uji Normalitas

\begin{tabular}{llr}
\hline & & CAR \\
\hline $\mathrm{N}$ & & 71 \\
Normal Parameters & Mean & -.0059 \\
& Std. Deviation & .0233 \\
Most Extreme Differences & Absolute & .086 \\
& Positive & .080 \\
Test Statistic & Negative & -.086 \\
Asymp. Sig. (2-tailed) & & .086 \\
Sumber: Data diolah, 2018 & & .200 \\
\hline
\end{tabular}

Pengujian hipotesis ini menggunakan uji one sample t-test yang diolah dengan software IBM SPSS Statistics 23. Hasil uji hipotesis 1 dapat dilihat dalam tabel 7 berikut ini: 
Tabel 7.

Uji One Sample T-Test

\begin{tabular}{lcccccc}
\hline & & \multicolumn{2}{c}{ Test Value $=\mathbf{0}$} & \multicolumn{2}{c}{ 95\% Confidence Interval of } \\
& & & $\begin{array}{c}\text { Mean } \\
\text { the Difference }\end{array}$ \\
& $\mathbf{t}$ & Df & Sig. (2-tailed) & Difference & \multicolumn{2}{c}{$\begin{array}{c}\text { Lower } \\
\text { Upper }\end{array}$} \\
\hline CAR & .653 & 82 & .515 & .0023 & -.0047 & .0093 \\
\hline Sumber: Data diolah, 2018 & & & & &
\end{tabular}

Berdasarkan tabel uji one sample t-test diperoleh nilai $\mathrm{t}=0,653$ dengan nilai probabilitas sebesar $0,515>\alpha(0,05)$, yang berarti berarti bahwa tidak terdapat reaksi pasar atas pengumuman dividend initiation, atau $\mathrm{H}_{1}$ ditolak dan $\mathrm{H}_{0}$ diterima.

Pengujian hipotesis ini menggunakan uji one sample t-test yang diolah dengan software IBM SPSS Statistics 23. Hasil uji hipotesis 2 dapat dilihat dalam tabel 8 berikut ini:

Tabel 8.

Hasil Uji One Sample T-Test

\begin{tabular}{|c|c|c|c|c|c|c|}
\hline & \multicolumn{6}{|c|}{ Test Value $=0$} \\
\hline & \multirow[b]{2}{*}{$\mathbf{t}$} & \multirow[b]{2}{*}{ Df } & \multirow[b]{2}{*}{ Sig. (2-tailed) } & \multirow{2}{*}{$\begin{array}{c}\text { Mean } \\
\text { Difference }\end{array}$} & \multicolumn{2}{|c|}{$\begin{array}{l}95 \% \text { Confidence Interval of } \\
\text { the Difference }\end{array}$} \\
\hline & & & & & Lower & Upper \\
\hline CAR & -2.134 & 70 & .036 & -.0059 & -.0114 & -.0003 \\
\hline
\end{tabular}

Berdasarkan tabel uji one sample t-test diperoleh nilai $\mathrm{t}=-2,134$ dengan nilai probabilitas sebesar $0,036<\alpha(0,05)$, yang berarti berarti bahwa terdapat reaksi pasar yang negatif atas pengumuman dividend omission, atau $\mathrm{H}_{2}$ diterima dan $\mathrm{H}_{0}$ ditolak.

Pengumuman pembagian dividen yang dilakukan oleh perusahaan dikatakan memberikan sinyal bagi pasar baik positif maupun negatif, maka pasar akan bereaksi yang ditunjukkan dengan adanya abnormal return. Berdasarkan pengujian hipotesis yang telah dilakukan, dapat disimpulkan bahwa hipotesis 1 
yaitu pasar bereaksi positif atas pengumuman dividend initiation ditolak. Hal ini menunjukkan bahwa selama 3 hari pengamatan pengumuman pembagian dividen tidak mengandung informasi yang berharga bagi investor dan tidak memengaruhi keputusan investasi.

Reaksi pasar yang tidak sejalan dengan bird in the hand theory ini dapat disebabkan oleh perilaku investor yang masih ragu-ragu kepada perusahaan yang melakukan dividend initiation. Investor memandang bahwa mungkin perusahaan tidak akan membagi dividen di periode selanjutnya, karena baru pertama kali perusahaan membagikan dividen setelah sebelumnya tidak membagikan dividen. Perusahaan yang melakukan dividend initiation tidak langsung membuat investor bereskpektasi tinggi, karena investor pasti memerhatikan laporan keuangan perusahaan. Jika investor memerhatikan laporan keuangan perusahaan sebelum mengambil keputusan, maka investor tidak akan terburu-buru mengambil keputusan investasi hanya karena perusahaan mengumumkan akan membagikan dividen.

Hasil dari penelitian ini sejalan dengan penelitian sebelumnya yaitu: (Indrawati, 2013) menyatakan bahwa variabel dividend initiation sebelum pengumuman tidak berpengaruh positif dan signifikan terhadap reaksi pasar. Penelitian ini dilakukan pada perusahaan manufaktur yang terdapat di Bursa Efek Indonesia periode 2007-2011, dengan sampel 14 perusahaan. (Sharma dan Pandey, 2015) menyatakan pengumuman dividend initiation tidak berpengaruh terhadap perubahan harga saham terlepas dari kapitalisasi perusahaan. Penelitian ini dilakukan di Indian Stock Market dengan sampel 103 perusahaan. 
Ni Putu Adi Pertiwi dan Dewa Gede Wirama. Reaksi...

Berdasarkan pengujian hipotesis yang telah dilakukan, dapat disimpulkan bahwa hipotesis 2 yaitu pasar bereaksi negatif atas pengumuman dividend omission diterima. Hal ini menunjukkan bahwa selama 3 hari pengamatan, pengumuman pembagian dividen mengandung informasi yang berharga bagi investor dan memengaruhi keputusan investasi.

Hasil dari pengujian ini sejalan dengan penelitian sebelumnya yaitu: (Purwanto, 2013) yang menyatakan bahwa pengumuman dividen omisi terhadap abnormal return memberikan reaksi yang negatif dan signifikan. Penelitian ini dilakukan pada perusahaan yang melakukan dividen omisi periode tahun 20082017. (Chelimo dan Kiprop, 2017) yang melakukan penelitian di Bursa Efek Nairobi dengan periode penelitian 10 tahun menyatakan bahwa penurunan jumlah pembayaran dividen menyebabkan penurunan harga saham di Bursa Efek Nairobi.

Implikasi teoritis hasil penelitian ini adalah diketahuinya pengumuman dividend initiation tidak direaksi oleh pasar, dan pengumuman dividend omission direaksi negatif oleh pasar. Penelitian ini juga dapat digunakan sebagai sumber referensi bagi penelitian selanjutnya, karena hasil pengujian dari pengumuman dividend initiation tidak mendukung signalling theory.

Implikasi praktis dari penelitian ini adalah investor adalah investor dapat memerhatikan pengumuman dividen yang dilakukan oleh perusahaan, baik itu pengumuman pembagian dividen untuk pertama kalinya atau penghapusan dividen untuk pertama kalinya. Variabel tersebut dapat menjadi pertimbangan investor dalam menentukan keputusan investasi. 


\section{SIMPULAN}

Pengumuman dividend initiation tidak direaksi oleh pasar. Hal tersebut dapat dilihat dari hasil pengujian hipotesis 1 dengan menggunakan uji one sample t-test didapatkan nilai t sebesar 0,653 dengan probabilitas sebesar 0,515>0,05.

Pengumuman dividend omission direaksi negatif oleh pasar. Hal tersebut dapat dilihat dari hasil pengujian hipotesis 2 dengan menggunakan uji one sample t-test didapatkan nilai t sebesar -2,134 dengan probabilitas sebesar 0,036 $<0,05$.

Investor dapat memerhatikan pengumuman pembagian dividen atau penghapusan dividen untuk dapat menentukan keputusan investasi. Penelitian selanjutnya dapat meneliti kembali dengan: (1) metode yang berbeda, (2) memperpanjang periode amatan, (3) menggunakan event window yang lebih dari 3 hari, (4) menggunakan tanggal event lain, seperti tanggal pengumuman, tanggal pencatatan, atau tanggal pembayaran dividen, (4) menggunakan salah satu sektor dari sembilan sektor yang ada di BEI agar mendapatkan hasil yang lebih representatif.

\section{REFERENSI}

Asquith, P \& Mullins, D. W. (1983). The Impact of Initiating Dividend Payments on Shareholders' Wealth. Journal of Business, 56(1), 77-96.

Brown, S.J \& Warner, J. B. (1985). Using Daily Stock Return: The Case of Event Studies. Journal of Financial Economics, 14(1), 3-31.

Chelimo, J. K., \& Kiprop, S. K. (2017). Effect of Dividend Policy on Share Price Performance: A Case of Listed Insurance Companies at the Nairobi Securities Exchange , Kenya. International Journal of Accounting, Finance, and Risk Management. 2(3), 98-106. https://doi.org/10.11648/j.ijafrm.20170203.12 
Dharmarathne, D. G. (2013). Stock Price Reaction To Dividend Announcements and Information Efficiency in Sri Lankan Share Market. International Journal of Research In Social Sciences, 3(2), 100-111.

Fadhilah, D. N. (2017). Pengaruh Dividend Omissions Terhadap Risiko Investasi dan Profitabilitas. Jurnal Akuntansi Unesa, 6(1).

Gumanti, T.A. (2013). Kebijakan Dividen, (Teori, Empiris, dan Implikasi). Yogyakarta. UPP: STIM YKPN

Handayani, N. (2015). Analisis Reaksi Pasar Sebelum dan Sesudah Pengumuman Dividend Omissions (Studi Pada Perusahaan di Bursa Efek Indonesia Periode Tahun 2010-2014. Skripsi. Universitas Sebelas Maret.

Hartono, J. (2016). Teori Portofolio dan Analisis Investasi (Kesepuluh). Yogyakarta: BPFE.

Indrawati, N. (2013). Pengaruh Pengumuman Dividend Initiation dan Dividend Omission Terhadap Reaksi Pasar Pada Perusahaan Manufaktur yang Terdaftar di Bursa Efek Indonesia.Skripsi. Universitas Muhammadiyah Surakarta.

Muhajir. (2016). Pengaruh Kepemilikan Manajerial, Likuiditas,Profitabilitas, Ukuran, dan Laverage Perusahaan Terhadap Kebijakan Dividen Perusahaan. Universitas Muhammadiyah Yogyakarta.

Priya, Vidya. P dan Mohnasundari, M. (2016). Dividend Policy and Its Impact on Firm Value: A Riview of Theories and Empirical Evidence. ApeejayJournal of Management Science and Technology, 3(3), 59-69

Purwanto, J. (2013). Pengaruh Pengumuman Dividen Inisiasi dan Dividen Omisi Terhadap Abnormal Return pada Perusahaan Manufaktur yang Terdaftar di Bursa Efek Indonesia (BEI) Periode Tahun 2008-2011. Skripsi.Universitas Maritim Raja Ali Haji Tanjungpinang.

Sharma, J. K., \& Pandey, V. S. (2015). Effect of Dividend Initiation and Omission on Share Prices in Indian Stock Market. Advances in Economics and Business Management (AEBM), 2(3), 255-259.

Suparsa, I Made Joni, dan Ratnadi, Ni Made Dwi. (2014). Perbedaan Abnormal Return dan Trading Volume Activity atas Pengumuman Kenaikan Harga BBM pada Saham yang Tergolong LQ45. E-Journal Akuntansi Universitas Udayana 7(2), 382-390. 
Sare, Y. A., Pearl-Kumah, Seyram dan Salakpi, A. (2014). Market Reaction to Dividend Initiation Announcements on The Ghana Stock Exchange: The Case of Industrial Analysis. Asian Economic and Financial Riview, 4(4), 440-450.

Wicaksono, G. A. (2016). Reaksi Investor Sebelum dan Sesudah Pengumuman Dividend Initiation dan Dividend Omission pada Perusahaan yang Terdaftar di Bursa Efek Indonesia (BEI) pada Tahun 2010-2015. Universitas Lampung. 